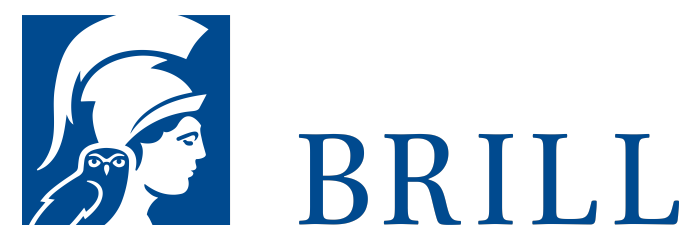

\title{
Mediale Repräsentationen der Kaiserin Elisabeth von Österreich
}

Sissi in Film, Operette und Presse des 2o. Jahrhunderts

Author: Nicole Karczmarzyk

Von Elisabeth zu Sissi - Schicksalsjahre einer Filmfigur. Wie die österreichische Kaiserin zum Medienstar wurde und welchen Funktionen die Figur unterliegt.

Die systematische Analyse politischer Mythologie um Elisabeth von Österreich aus medienkulturwissenschaftlicher Perspektive zeigt die >mythische Logik $<$ hinter den medialen Repräsentationen der populären >Sissi< auf. Über einen Zeitraum von einem Jahrhundert werden die intertextuellen Muster beschrieben, die immer wieder auf die gleichen narrativen Bausteine zurückgreifen und je nach zeithistorischem Kontext und Genre jeweils neuen Interpretationen unterworfen werden. Neben Ernst Marischkas Sissi-Trilogie stehen ebenso Stummfilme und HollywoodProduktionen im Zentrum der Analyse. Ein Ausblick skizziert die Entwicklungen in den Darstellungen der Kaiserin seit den 1970er Jahren sowie die Verknüpfungen zu weiteren >mythischen Figuren .

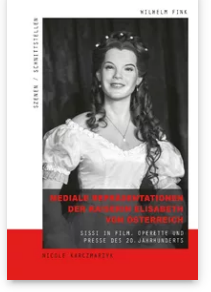

Pages: 227

Seiten, $14 \mathrm{~s} / \mathrm{w}$

Abb.

Language:

German

Subjects:

General, Media

Studies

Publisher: Brill |

Fink

Series:

Szenen/Schnittstellen,

Volume: 2

E-Book (PDF)

Released online:

16 Sep 2019

ISBN: 978-3-

8467-6214-1

List price

Paperback

Publication date:

11 Aug 2017

ISBN: 978-3-

7705-6214-5

List price 
Studium der Literaturwissenschaft an der Universität Bielefeld, später wissenschaftliche Mitarbeiterin im ATTRACT-

Forschungsprojekt „Ästhetische Figurationen des Politischen“

For more information see brill.com

Order information: Order online at brill.com +44330 3330049 | customerservices@brill.com Submission information: brill.com/authors

Titles published by Brill | Fink, Brill | mentis or Brill | Schöningh: +49(o)71 5413279216 | brill@brocom.de 